\title{
Marketing Missions: Material Culture, Theological Convictions, and Empire in 18th-Century Christian Philanthropy
}

\author{
Philippa Koch \\ Department of Religious Studies, Missouri State University, Springfield, MO 65897, USA; \\ PhilippaKoch@MissouriState.edu
}

Received: 1 June 2018; Accepted: 27 June 2018; Published: 3 July 2018

\begin{abstract}
In the 18th century, Halle Pietists were part of a global missionary network that reached into North America and that anticipated later developments in worldwide evangelical missions; Pietists made critical alliances with other Protestants, they were savvy in their use of media, and they worked alongside different empires in their efforts to reach and convert the world. Recent scholarship on religion and humanitarianism in the United States has focused predominantly on the Anglo-American story and the Post-Revolutionary period. This article argues that the Pietists highlight an earlier-and crucial—colonial era of global missionary connections, philanthropy, media, and empire. Attending to their writings and the images they used reveals important and continuing themes in the study of Christian philanthropy in America, including the significance of theological convictions, financial necessities, political allegiances, and racialized imaginings of potential, "uncivilized" converts. This article looks at the image of ascending eagles from the orphan house in Halle, which the Francke Foundations (earlier the Glauchasche Anstalten) used for their seal on books and medicines, and also considers an engraving of Tomochichi, a leader of Yamasee and Lower Creek descent, who appeared in the first report from the Pietist mission in colonial Georgia. The article argues, finally, that images were used to sell a particular vision of missionary work, albeit one that was not always true to experience on the ground and that appealed to colonialist objectives.
\end{abstract}

Keywords: Christianity; philanthropy; missions; images; Pietists; Francke Foundations; printers' marks; medicines; colonial Georgia; Native Americans

\section{Introduction}

On March 22, 1751, the Lutheran minister Heinrich Mühlenberg hiked with friends in the mountains near Tulpehocken, Pennsylvania. After about three miles, they reached a peak from which they looked over the valleys below and watched as three eagles soared above them. In his journal, Mühlenberg described the eagles,

... gradually wheeling upwards in circles and climbing ever higher into the golden sea of the streaming springtime sun, becoming smaller and smaller to our eyes until finally they were almost lost from sight. The hearts and minds of us all were inspired by the sight. In Glaucha [later Halle] we had the representation of this on the façade of the blessed institutions [of the orphans' home]. Here we saw the living picture and it gave us an even more vivid idea of the matter there portrayed.

(Muhlenberg 1942, pp. 270-71)

In the wilds of Pennsylvania, Mühlenberg was captured by an image from his German education and home-from the center of 18th-century Lutheran Pietist missions and benevolence: the Francke 
Foundations of Halle, in Prussia. There, on the tympanum of the Foundations' historic orphan house, was the image of eagles that Mühlenberg recalled (Figure 1). The Foundations' eagles fly toward the sun as with strength renewed by faith-so described by the scriptural passage rippling on the banderol below: "Die auf den Herrn harren, kriegen neue Kraft, daß sie auffahren mit Flügeln wie Adler" ("They that wait upon the LORD shall renew their strength; they shall mount up with wings as eagles." Isaiah 40:31; King James Version—-the contemporary English-language Protestant Bible).

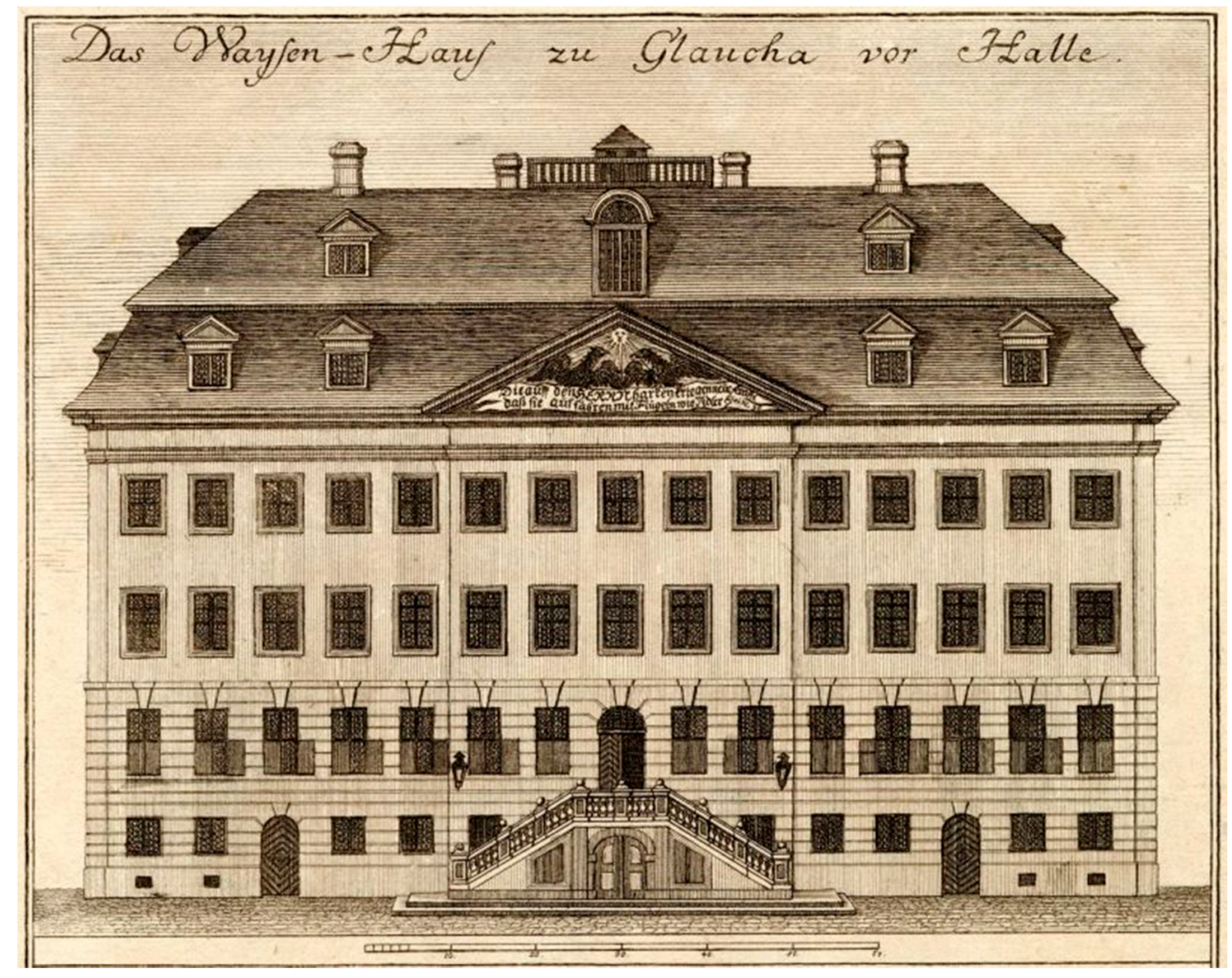

Figure 1. Engraving of the main orphan house of the Francke Foundations (Grundler 1749). Gottfried August Gründler, The Francke Foundations in Halle. 1749. Public Domain.

Images played an important role in the global Pietist missionary network, of which Mühlenberg was a well-known representative in early America. The image of the eagles on the orphanage tympanum, in particular, became significant to institutional centralization. With increasingly far-flung missionary networks, the seal of the Francke Foundations-which reflected the eagles on the tympanum - was a familiar mark on both the books and the medicines the Foundations produced, sold, and sent around the world. The evocative seal marked the Foundations' products, establishing its brand and raising funds necessary for further benevolent and missionary work, which, for Pietists, went hand-in-hand. With the seal and other artwork, including engravings, the Foundations successfully fostered a community of benefactors who longed to participate in and read about the Pietists' missionary efforts. As Mühlenberg's words suggest, these images helped to create and maintain loyalty to the theological vision and mission crafted at the Foundations, even at great geographical distance. The Pietists also, however, used the seal and other images to inscribe a particular story of Christian mission onto the colonial landscapes they touched. This was a story likewise crucial for the promotion of their community, success, and self-understanding, yet it was a story that nonetheless participated in and perpetuated the racial assumptions and colonial discourse that accompanied imperial expansion. 


\section{Missions, Marketing, and Empire in Modern Christianity}

The study of modern Christian philanthropy demands attention to the deep-seated connection between theological conviction, Protestant material culture, and the wider political world. Theological ideals motivated many Protestant communities' participation in, commitment to, and success in their outreach, benevolence, and reform. Attending to Protestant material culture-including texts, printers' marks, book production, trading networks, engravings, and maps-at the same time, throws into relief broader social norms and prejudices that religious communities have accommodated, contributed to, pushed against, or wholeheartedly embraced in their dogged pursuit of theological convictions. The missions associated with the Francke Foundations offer an early and significant example of the Protestant use of images and marketing toward the purposes of evangelism and benevolence. The Pietists pioneered printing techniques and sold medicines, showcasing an impressive organizational prowess in their pursuit of mission. They also engaged colonial visions of civilization, printing engravings of "noble Indians" and enlightened town plans within their reports for benefactors. Forerunners of 19th- and 20th-century American evangelicals and global humanitarian initiatives, missionaries of the Francke Foundations worked alongside emerging consumer culture and political authorities in their earnest effort to expand God's kingdom.

The American public and scholars alike often have trouble reconciling Christian efforts to evangelize and help people with Christian participation in the marketplace, contemporary media, and political culture. A well-known and oft-critiqued example of the merging of Christianity, the market, and media in the modern United States is the so-called "Prosperity Gospel" movement, which has been enormously successful but has also garnered widespread disparagement in popular American culture. With their splashy use of marketing, fashion, and music, churches associated with this movement are often characterized as manipulative, shallow, and "sanitized" forms of Christianity, focused on fulfilling "psychological need" and offering "false hope" by fixating on material signs. Even political commentators and think tanks are paying attention to the intersection of Christianity, economics, and material success, due in large part to the influence of Prosperity Gospel preachers in the presidential administration of Donald Trump (Oliver 2015; Powers 2018; Pendergrass 2017; O'Hanlon and Turner 2017). Many Americans are prone to view such religious use of and adaptation to the marketplace and political realm with a suspicious eye to ulterior motives. By engaging so avidly in secular and political culture, some surmise, these Christians are more interested in gaining profit and power than actually healing souls and society. Scholars have shown, nonetheless, that theological convictions simultaneously undergird these movements and practices (Bowler and Reagan 2014, pp. 208-11).

The discomfort surrounding Christian participation in the marketplace and politics is shaped by two scholarly strands. The first insists on a Protestant aversion to images and objects in both theology and practice. Sally Promey has argued that "part of the narrative and theoretical/theological work of both modernization and Reformation concerned a process of disenchantment of the material universe in favor of 'spiritual' transformation, with god(s) resident in believing hearts rather than external objects". Scholars have rightly portrayed Protestant anxieties about the corruptive potential of icons and images to an internalized "faith"; indeed, "various Protestantisms and modernities have each had much to say about the ways people should (and should not) practice objects". Yet describing such Protestant teachings is, as Promey argues, "insufficient to contain the way people actually do [practice objects]". Uncritical interpretations of Protestant material culture in practice nonetheless often continue to shape scholarly and public attitudes, despite significant studies of the rich Protestant traditions of material culture and ritual (Promey 2011, pp. 183-84, 208-10; Morgan 1998, pp. 152, 183; McDannell 1995, pp. 26-27; Finch 2009, pp. 4-5; Hall 1989, p. 19).

The second scholarly strand is focused on the intersections of benevolence and social discipline or social control. Influenced by Marxist and Foucauldian interpretations, scholars have often discounted religious impulses to benevolence or perceived hypocrisy in charity and social reform efforts-and particularly when these efforts made use of media and contributed to the ends of governing authorities. Such scholars perceive sinister motives of worldly power in reformers' social engagement and vision. 
More recently, however, historians have pushed back against these interpretations, recognizing the diverse and complex individual, social, and cultural forces at work in benevolence and reform work (Banner 1973, pp. 23-41; Conroy-Krutz 2015, pp. 9-11; Curtis 2018, p. 293; Davis 1975, p. 34; Dayton and Salinger 2014, p. 5; Frohman 2008, pp. 2-9; Haskell 1985, pp. 339-43; McCarthy 2003, pp. 13-23; Moniz 2016, pp. 12-16; Ryan 2004, pp. 1-21; Wandel 2003, pp. 14-16; Wright 1992, pp. 10-11).

Scholars of religious philanthropy and its ties to broader political objectives have sought a more nuanced approach to how missionaries and reformers themselves construed their work theologically and, at the same time, worked in cultural contexts shaped in myriad ways by nation- and empire-building (Conroy-Krutz 2015; Curtis 2018). Transatlantic and, eventually, global Protestant (or "evangelical") humanitarians have served as agents of empire in critical ways, forging American and global ideologies of civilization, progress, and expansion alongside their missionary work (Moniz 2016). Much of this recent work follows Susan Ryan's approach of "strategic credulity" when it comes to ascertaining the motivations of early American reformers. While not "preclud[ing] judgment", it is nonetheless worthwhile to begin our study by "taking seriously the good intentions" of early Americans (Ryan 2004, pp. 4-5).

Ryan's approach helps reveal not only the motivations of Christian missionaries and reformers but also the cultural norms with which they lived (and to which they contributed). Heather Curtis' study of late-19th- and 20th-century evangelical charity, for example, makes "visible the theological principles, economic assumptions, racial biases, nationalist aspirations, gendered suppositions, and religious convictions that have shaped the meaning, practice, and trajectory" of Protestant humanitarian aid (Curtis 2018, p. 293). Looking to material culture is one way to find these intersections. 18th-century Protestant missionaries and philanthropists used the marketplace and images to control their messages and organizations while also promising spiritual transformation. Like Christianity, the consumer culture in which these Protestants participated promised transformation. Capitalism, as Promey has shown, "connects its material products to 'inner' abstractions and to promises/fantasies of transcendence" (Promey 2011, pp. 208-9).

The Francke Foundations and their missionary images demonstrate the significance of attending to Protestant benevolence and material culture in the colonial Atlantic world. Operating before the rise of the American nation and between complex political and denominational alliances, the Francke Foundations developed and exemplified the philanthropic savvy necessary to support core theological visions, institutional centralization, economic survival, and widespread public and political engagement. The Halle Pietists accomplished this, in part, through a central, institutional brand that served as a reminder of the theological motivations behind missionary endeavors as they told a story of Christian perseverance, growth, and civilization that invited extensive participation and transcended political boundaries. Their use of images in mission materials represents an important colonial moment in what would become a lasting story of the role of Christian benevolence and mission in the spread of western empires.

\section{A Pietist Brand and Theological Vision}

Although infrequently mentioned in histories of American Christianity and philanthropy, the Francke Foundations were an early and key player in the revivals, missions, and benevolent endeavors of the 18th-century Atlantic world. The Foundations shaped Protestant ideas of education, print, medicine, and missionary outreach beyond the German-speaking world, particularly through their connections to the British and Danish empires as well as through print and the personal connections and correspondence of ministers, missionaries, benefactors, and laity. From Cotton Mather and George Whitefield to Sarah Osborn and the Wesley brothers, stories of the Francke Foundations' good works were widespread and inspiring for emerging Anglo-American evangelism (Hindmarsh 2018, pp. 21-27; Osborn 1758; Ward 1992, pp. 273-76).

Initially founded as a charity school in 1695 in Glaucha, the Foundations grew to include an orphan house (Waisenhaus), a medical dispensary, and a printing press, as well as the connected Hallische 
Bible Institute. The Bible Institute offers an illustrative example of the Foundations' significance for developing global Protestant missions and networks. Through the Institute, the Foundations participated in new printing techniques, which eventually allowed for the mass production of Bibles, devotional works, and other books—such as medical texts and missionary reports-essential to their larger evangelical and charitable endeavors. To give an idea of the effect of these printing innovations: in the century after the Luther Bible first appeared in 1522, 200,000 bibles were printed; in the 18th century, the Hallische Bible Institute produced two million bibles. The result was much more affordable publications, which could be translated and distributed throughout the Pietists' mission fields, from North America to the eastern coast of India, and the various political communities with which they worked (Wallmann 2005, pp. 120-21).

Many of the Francke Foundations' books carried the Foundations' distinctive mark. Particularly between the 1720s and 1740s, books from the Waisenhaus press appeared with a seal showing a man sowing seeds in a plowed field, a sun with many rays overhead, and some other form of agricultural or natural phenomena, such as trees, mountains, or hills (Figures 2-5). Overhead, one or two eagles soared toward the sun, and-always, at the top—appeared a banderol with the words "Illo Splendente Levabor" ("By his radiance I will be uplifted"). In the distance were often buildings, some of which suggested the main campus of the Francke Foundations, although the soaring eagles themselves unmistakably referred to the tympanum of the Foundations' central orphan house (Veltmann 2013).

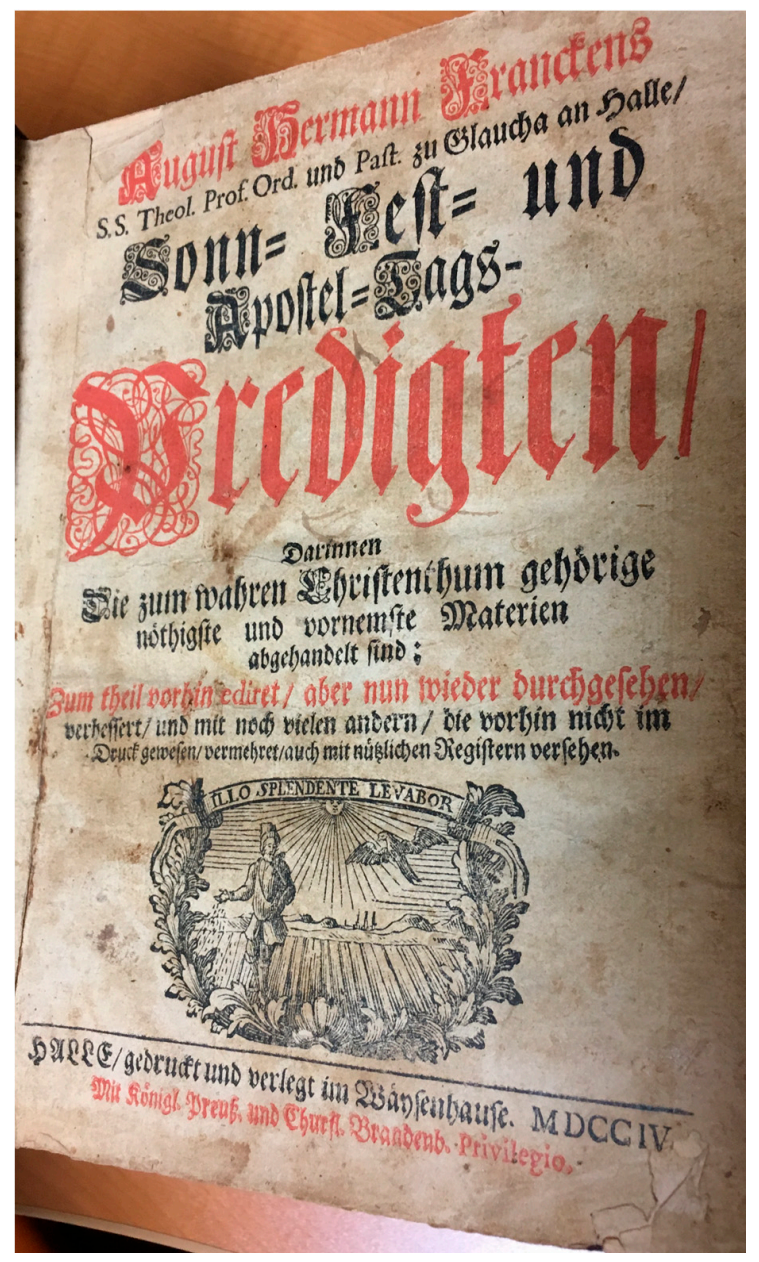

Figure 2. The seal as it appears on a full title page (Francke 1704). August Hermann Francke. Sonn-Fest-und Apostel-Tags-Predigten. Halle: Wäysenhause, 1704. Special Collections, A. R. Wentz Library, United Lutheran Seminary-Gettysburg. Photographed by author. 


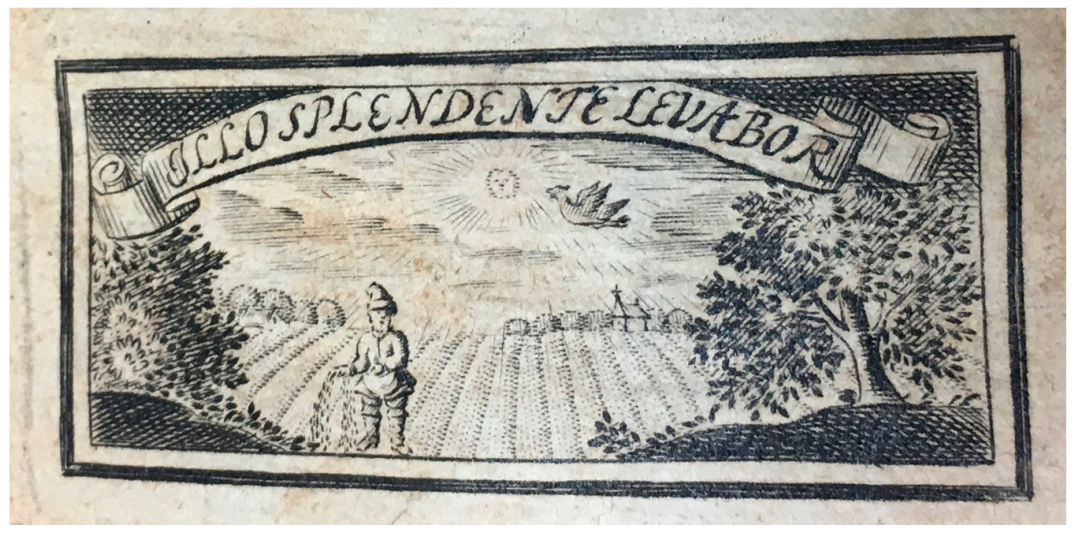

Figure 3. A 1722 version of the seal (Henckel von Donnersmark 1722). Erdmann Heinrich Henckel von Donnersmark, Die letzten stunden. Halle: Wäysenhaus, 1722. Special Collections, A.R. Wentz Library, United Lutheran Seminary-Gettysburg. Photographed by author.

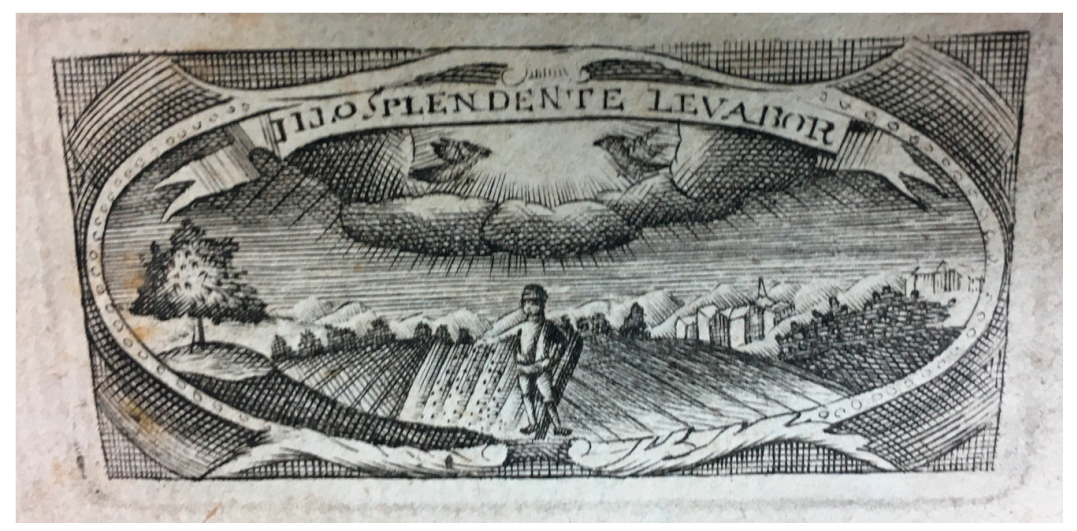

Figure 4. A 1731 version of the seal (Francke 1731). August Hermann Francke. Erklaerung der Psalmen Davids. Halle: Verlegung des Wäysen-Hauses, 1731. Special Collections, A.R. Wentz Library, United Lutheran Seminary-Gettysburg. Photographed by author.

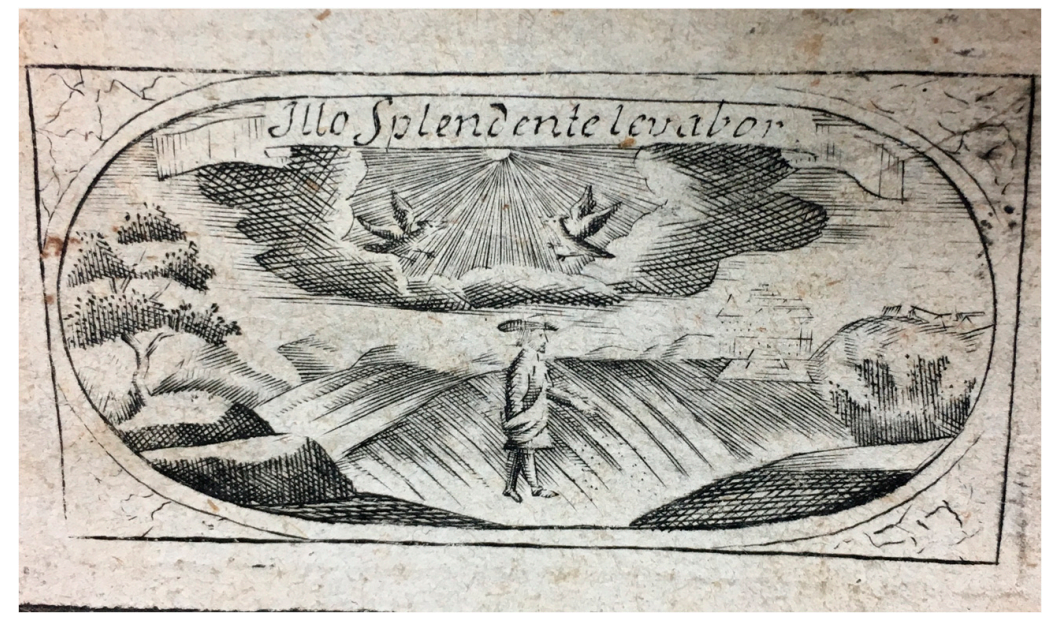

Figure 5. A 1740 version of the seal (Niekamp 1740). Johann Lucas Niekamp, ed. Kurtsgefastzte Missions-Geschichte oder Historischer Auszug der evangelischen Missions-Berichte aus Ost-Indien von dem Jahr 1705 bis zu Ende des Jahres 1736. Halle: Verlegung des Wäysen-Hauses, 1740. Special Collections, A.R. Wentz Library, United Lutheran Seminary-Gettysburg. Photographed by author. 
The history of printers' marks, which date to the 15th century, is inextricably bound to economic, political, and religious demands and contexts. The marks were early indicators of a book's origin, before it was standard consistently to include the details of publisher, place, and date-before, in fact, it was standard to have a title page. Printers' marks are easy to overlook; some are quite beautiful, but the significance of the design is not always clear and the designers, themselves, were rarely identified. The marks ranged in content; from an elaborate pun related to a printer's name to a mythical creature, like a unicorn, the marks might go unnoticed by modern scholars as a mere "device" of the print world, but marks were tools for business-minded printers and theologically-attentive church leaders alike. Marks could signal a well-reputed press and indicate the favor and official patronage of both royal and churchly authorities; marks, alongside authorship and place of publication, could also be forged in order to garner business or, perhaps, for self-protection. Such practices were common enough during the Reformation that some local German authorities sought to curb abuses by demanding "prior inspection of any texts likely to prove controversial", a measure that increased forgeries. The second decree of the Council of Trent (issued in 1546), meanwhile, targeted printers who produced and sold unauthorized scriptures or religious books with false author attribution and lack of prior official examination and approval (Roberts 1893, pp. 1-11, 33-43; Pettegree 2015, pp. 272-80; Leith 1963, pp. 403-5).

Although distant from Reformation-era debates, the mark of the Francke Foundations likewise demonstrated a commitment to both political authorities and a particular theological vision. The eagle (or eagles) in the mark, it has been suggested, may have reflected the eagle in the Prussian coat of arms, acknowledging the patronage the Francke Foundations received from the Prussian kingdom under Friedrich I, who also founded the University of Halle, to which the Francke Foundations were connected. (Bruun et al. 2015, pp. 302-3; Veltmann 2013). More explicitly, however, the mark referenced the tympanum of the main orphanage building itself-both pictorially, with its flying eagles, sun, and banderol, and textually, with its Latin phrase "Illo Splendente Levabor" referring to the same scriptural promise as the tympanum's text and image from Isaiah 40:31.

The Francke Foundations were eager to maintain control over their printed works for both economic and religious reasons and in multiple political contexts. The reach of this control is exemplified in developments in the German-language book market in the American colonies. The Foundations' books were influential among German readers in North America, where the books were distributed through the Foundations' missionary networks and with the financial support of generous European benefactors. Letters from the mission field often mentioned and requested books (Boltzius and Gronau 1743; Boltzius 1749; Boltzius 2009, pp. 356, 532-33, 775-76). While German-language printers did develop in North America-including the well-known Philadelphian Christopher Sauer-the Francke Foundations refused to assist them. In the 1730s, they rejected Sauer's request for help obtaining the gothic letters German readers preferred. Anxious about Sauer's radical views, Gotthilf Francke, the Foundations' leader at the time, "gave first priority to absolute control of their media apparatus". Francke even initially refused the requests of Heinrich Mühlenberg, a missionary appointed to Pennsylvania by Francke himself. Mühlenberg sought assistance in establishing a press in Pennsylvania with the goal of combatting the growing reach and popularity of Sauer's radical printings. Despite Francke's concern to maintain control, the Foundations did, eventually, agree to help Mühlenberg (Müller-Bahlke 2000, pp. 153-54; Leaman 2014).

In addition to books, the Francke Foundations also controlled the proprietary medicines they produced, used, and sold throughout European lands and in missionary fields. These medicines typically featured a colorful adaptation of the same mark the Foundations used in publications. The elaborate seal included a coat of arms made up of a navy helmet and unfurling golden ribbons around a white shield that carried the name of the medicine. Above this coat of arms, two dark eagles with yellow beaks and talons flew upward toward a central sun, which was stylized with sixteen rays and a face ( n.d.). The seal for the medicines quickly became recognizable and familiar. Customers looked for the mark of the Foundations; it was an important part of what made the medicines trustworthy and sought after, and generic and counterfeit versions did not sell as well. The 
"firmly sealed bottles with the Orphanage seal clearly displayed," the historian Renate Wilson argued, offered a guarantee that the medicines within were indeed those well-known for their consistency and quality (Wilson 2000, pp. xi-xii, 76-78).

Medicine was a part of Christian mission that crossed political boundaries. The Foundations perceived and enunciated a Christian duty to help the sick; medical treatment was a form of evangelism - saving bodies was a means to save souls—and the sales of medicines augmented the income of both the Foundations and their missionaries, allowing further evangelism. The Halle medicines were developed in affiliation with the medical university in Halle, in part through the treatment of orphans, students, and the local poor at the hospital of the Foundations. Christian Friedrich Richter, a leader in the development of the medicines, was a professor and physician who had trained under Georg Ernst Stahl and was strongly shaped by Halle Pietism. Medical care became so central to the Foundations' vision of evangelism that many missionaries completed some training in medicine before ordination. Mühlenberg, for one, recognized the importance of medicine to his work and longed to set up a dispensary in Philadelphia modeled on that of the Foundations. (As in the case of the printing press, the Foundations resisted.) Missionary ministers and physicians in North America nonetheless carried the Foundations' medicines with them as they began their work and ordered and dispensed medicines from the Foundations throughout their careers. The wives of Halle pastors, including Anna Maria Weiser Mühlenberg and her daughter, Margarete Kunze, who married another pastor trained at the Foundations, also ordered and dispensed the Foundations' medicines. In some cases-such as the community of Salzburger refugees in Georgia-the Foundations provided all medical care and medicines freely, through the support of benefactors in Europe. In other cases, the cost of the medicines-as with books - could be covered by the gifts and bequests of European benefactors, through patients' payments, or through a mixture of charity and payment. The medicines could also, occasionally, become a source of debt for missionary ministers, who might purchase and distribute them but receive no payment in return (Wilson 2000, pp. xvii-xix, 68-69, 71n25, 130-131; Koch 2016, pp. 552-57, 567-77).

The medicines moved easily across political borders throughout the 18th century because of the Foundations' recognizable brand, which linked the medicines to charitable, missionary, and philanthropic work. The Foundations only received the privilege to sell their medicines, for example, in areas "where no physicians and pharmacists were available", and thus for a time the medicines escaped notice as a competitive commodity of international trade. Critiques of the Foundations' commerce in medicine developed, nevertheless, in part because the Foundations refused to provide ingredients or formularies, which were increasingly called for in an era of pharmaceutical reform. Richter defended this approach, however, emphasizing the medicines' charitable origins and arguing that "yielding the monopoly of preparation and packaging would contravene the very purpose of the original bequests and the investment of time and financial resources". Were the Foundations to give out the formularies freely, the pharmacists of the wealthy could prepare them, and "no margin of profit [would] be diverted to charity" (Wilson 2000, pp. 72-74).

With charities competing constantly for funds and bequests, the international pharmaceutical trade of the Francke Foundations presented a means for their work to remain fully funded and "self-sufficient". The Foundations went to great lengths to extend their pharmaceutical trade to distant territories, often working through political alliances or acting as a financial intermediary for agents in other lands. The profits were incredible; according to Renate Wilson, "the total volume of this trade must surely have placed it in the top league of most European and English commerce in pharmaceuticals" of the mid-18th century. By the early 19th century, however, changing national politics, public health regulations, and rising tariffs all contributed to new state regulations that ended the ease of movement so central to the success of the Foundations' medicines. Medicine-within continental Europe-became identified more with profit than with charity, affecting the economic viability of the Foundations' pharmaceutical production and trade and, correspondingly, their larger mission (Wilson 2000, pp. 72-76, 80-83). 
With their seal, books, and medicines, the Francke Foundations aimed for brand recognition and loyalty as they sought income, expanded their global network of missions, and appealed to potential and continuing benefactors. The seal also, however, represented and reminded participants of the key theological convictions undergirding these enterprises. The two images combined within the printer's mark, in particular, clearly pronounced the Foundations' missionary goals: the mark joins the image and words from the orphan house tympanum (the eagles, the sun, and "Illo Splendente Levabor") with an image of a farmer sowing seeds. The printer's mark thus contains two scriptural references: Isaiah 40:31 and an allusion to New Testament passages equating right teaching with sowing seeds, important texts for missionary contexts (cf. Matthew 13, Mark 4, and Luke 8).

These scriptural references remind us that the seal was not merely a marker of a high-quality, global brand; the mark also reflected the Foundations' theological vision. As Kristian Mejrup argues, the printer's mark could be seen as a visual manifestation of August Hermann Francke's founding concept for his school. The motif of the sower in the field, joined with an eagle and sun, was used in the seal of Francke's Freitisch-the group of instructors and preceptors, who, beginning in 1696, taught at the Foundations' schools and received free meals in exchange for their efforts. From the beginning, Francke sought to establish a seminary that would "spread centrifugally to all estates of society, in and beyond Germany to Europe and the rest of the world". To do so required participants both to contribute actively to the cultivation of the field and to wait - to trust God's direction, oversight, and ultimate judgment over the plantation and final harvest (Mejrup 2015, pp. 433-34; Bruun et al. 2015, pp. 302-3, 319-20; Marschke 2014, p. 492).

This theological vision behind the seal was central to many who participated in the Foundations' mission. When Mühlenberg saw the eagles on his hike near Tulpehocken, he was among friends, taking a break from a visit to a new congregation and administrative tasks. They hiked back down to the world and the "lamentations" of another minister, knowing "we were no longer upon the mountain, but in [the wilderness] of Pennsylvania". Their sighting of the eagles, nonetheless, offered brief respite; it was a scene from the natural world that reminded Mühlenberg, above all, of the Francke Foundations' central visual imagery, corresponding scriptures, and theological conviction. Through faithful service, Mühlenberg hoped, he would be spiritually renewed and strengthened in his earthly tasks. He would seek to be a "Jeremiah who is able to hold out till the end and save the few who wait for the hope of Israel" — those fruits of the sown field (Muhlenberg 1942, pp. 270-71).

Three decades after Muhlenberg's hike, the image from the tympanum remained a significant symbol in North American Protestantism. Even when the Foundations were no longer actively involved in North American churches, this Pietist representation of Christian mission and benevolence endured. In the 1780s, the case for the new organ at Zion Lutheran Church in Philadelphia explicitly referenced the orphan house tympanum and seal of the Francke Foundations. Zion was an enormous church; one of the largest buildings in the colonies, it could seat 2500 and hosted, among other events, the memorial service for Benjamin Franklin in 1791. The 1780s organ case, designed by master joiner George Vorbach/Forepaugh, reached 27 feet above the congregation. Although the case was destroyed by a 1794 fire, Lisa Minardi has described it: "on the central tower was a painting of the sun rising above the clouds, flanked by gilded eagles and trumpeting angels on the side towers" (Minardi 2013, pp. 199-200). The organ and its massive case, with its soaring eagles, signaled both the economic flourishing of Lutherans in colonial Philadelphia and the continuing influence of the Francke Foundations' evangelical vision. The pastor at Zion during the organ's construction was Heinrich Helmuth, who had trained at the Francke Foundations. Together with congregation members, he founded The Society for the Support of the Honest Needy Poor in the 1780s. Like the Foundations, Helmuth's Society raised money from various benefactors through meetings and book sales in order to support its poor-relief program (1790; Roeber 1997).

The image of the eagles on Zion's organ was a visible sign of Pietism's success. An early and global endeavor in Protestant mission and benevolence, Halle Pietism demonstrated the power of 
centralized material culture, marketing, and theological message in its organization and work with multiple Protestant and political communities in the expanding colonial world.

\section{Engravings, Eagles, and Imperialism: Selling Missions, Philanthropy, and Civilization}

For the Francke Foundations, marketing and money had long been a central part of their missionary and charitable enterprises. Pietists saw money as an earthly, God-given resource, and proper stewardship of it supported the furtherance of the Foundations' work, mission, and message. Money-along with the books and medicines that helped bring it in-also represented an opportunity to involve and identify more people with the work of Christian benevolence and mission. When someone purchased a book or medicine, the seal (and the economic transaction itself) was a reminder of her or his contribution to the Foundations' work. Participation in and identification with the Pietist network and its evangelistic and philanthropic vision was also achieved through other forms of material and visual culture, including through engravings of important leaders and of missionary encounters with indigenous peoples and new landscapes. These engravings might be distributed independently or printed within significant volumes. For recipients and readers, engravings of potential converts and recently-mapped lands were visual reminders of their own identity as benevolent and engaged Protestants in a movement to explore, evangelize, and transform the expanding world of European colonization; images cemented the networks of fundraising, mission, and community that were essential to this effort.

In 1749, for example, Johann Boltzius, the missionary pastor among a community of Salzburger refugees in Georgia, thanked the Foundations for sending copper engravings of Gotthilf August Francke, then the director of the Foundations. Boltzius reported giving these engravings away to people who had served his community, including his wife Gertraud, his fellow pastor Heinrich Lemke, and the community's surgeon, Johann Mayer. He wished he had one more engraving to give to George Whitefield, an important friend, benefactor, and well-known English revivalist of the Atlantic world. Another time, Boltzius requested etchings for Whitefield's new Bethesda orphanage. The Pietists and Whitefield shared a vision of evangelism and philanthropy; indeed, Whitefield modeled Bethesda and his account of its founding on August Francke's work (Boltzius 2009, pp. 496, 521, 622; Francke 1709; Whitefield 1742). The engravings and etchings that Boltzius sought to give Whitefield were a visual token that reinforced their mutual work and theological vision while also expressing gratitude for the service and funds Whitefield contributed to the Salzburger mission.

The Foundations' support of the Salzburger refugees in Georgia proved to be an incredibly popular cause among European benefactors, and, recognizing this, the Foundations published and distributed regular updates on the community. The expulsion of approximately 20,000 Protestants from Salzburg between 1731 and 1732 - and their resettlement in places like East Prussia-had already been the subject of much media attention. When the Francke Foundations joined the Georgia Trustees and the Society for the Promotion of Christian Knowledge to invite a small group of the refugees to the new colony of Georgia, the marketing opportunity proved enormous for these vanguards of Protestant global missions. The Foundations assigned two Halle-trained ministers to accompany the first transport of refugees in 1734 to Georgia-or the "West Indies", as the colony was referred to in early correspondence. Among their many responsibilities, these ministers were tasked with recording detailed reports of their community's daily activities for eventual publication in Europe. Their supervisors and editors there recognized that mission accounts, distributed and sold widely, could offer both "spiritual and material" blessings to the Foundations and its work (Melton 2008, pp. 108-11; Walker 1992, pp. 197-98; Boltzius 2009, pp. 323-27).

The Pietists saw in this first North American mission an opportunity to depict not only the sensational story of the Salzburger refugees, but also the "civilizing" potential of their missionary work in the new English colony. The first publication of the Salzburger reports appeared in 1741 and was bookended by two elaborate engravings: the first of the "Yamacraw King" Tomochichi (spelled "Tomo Chachi" in the accompanying caption) with his nephew Toonahowi, and the second an idealized map 
of the County of Savannah (Figures 6 and 7). The reports that appeared between these engravings had been extensively edited and adapted by an Augsburg Pietist named Samuel Urlsperger, who worked closely with Gotthilf Francke in Halle in preparing the publication. The reports are full of detailed stories of a distant and unknown land, the difficult challenges of settlement, the new diseases encountered, and thankful letters to benefactors from the Salzburgers themselves. Yet Urlsperger did not rest on these details as he sought to reach and command a large audience of sympathetic benefactors; rather, he chose to begin and end the account with the engravings of two Indians and a map (Urlsperger 1741).

Urlsperger anticipated the popularity of both engravings. He wrote to Gotthilf Francke in Halle that the engraver Johann Jacob Kleinschmidt was preparing the images for inclusion in the reports. Kleinschmidt had previously worked on important engravings for the Foundations' publications, including one of the Salzburger expulsion and one of Tranquebar, a mission site on the eastern coast of India, where the Foundations worked with the Danish crown. Kleinschmidt planned the Georgia engravings, Urlsperger explained, such that they could be unfolded to a larger scale than the book allowed and even be removed from the books, should the owner or reader so desire (there was no print on the reverse page) (Urlsperger 1735).

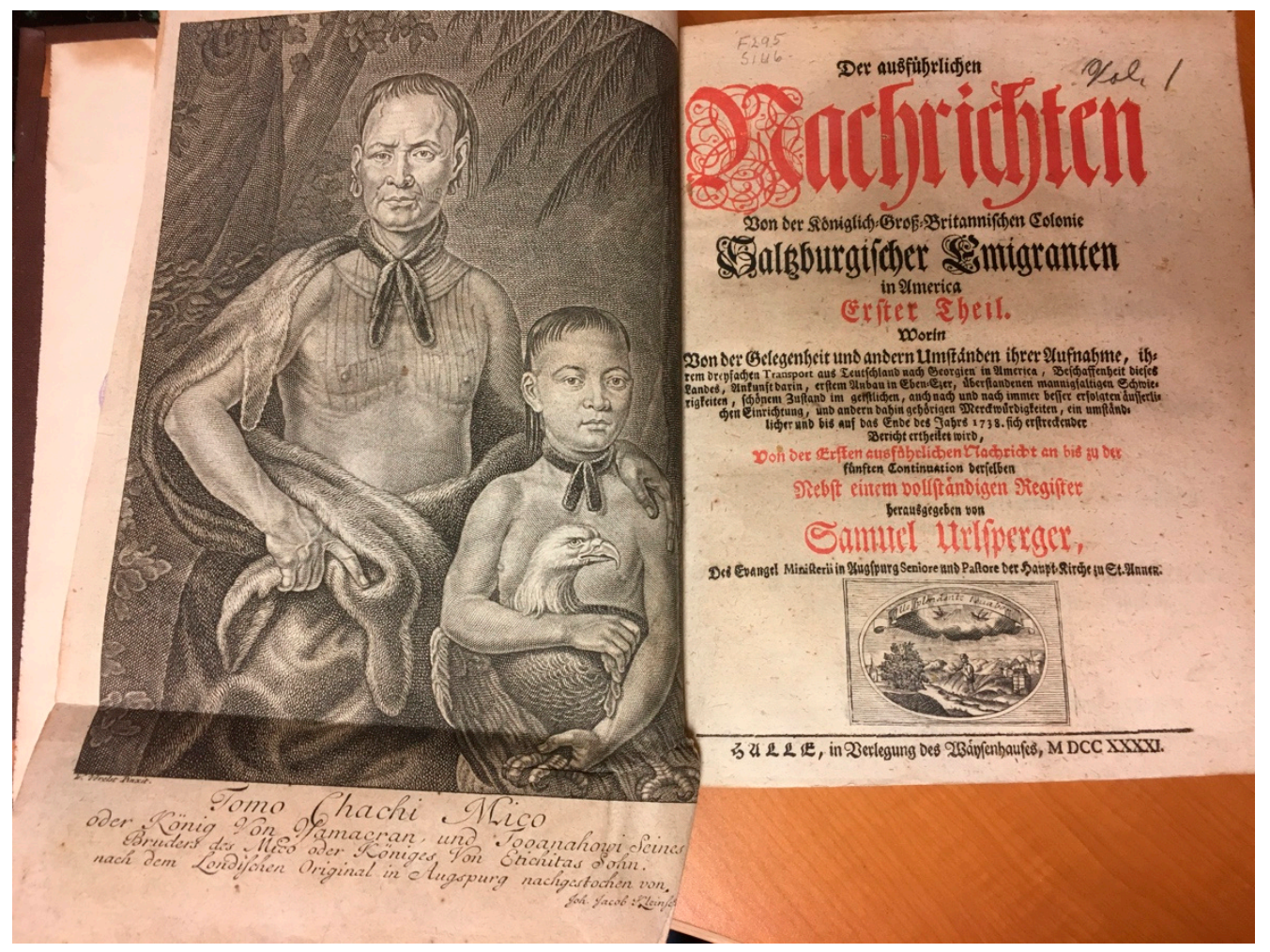

Figure 6. Engraving of Tomochichi and Toonahowi as it appears in the Detailed Reports (Urlsperger 1741). Samuel Urlsperger, ed. Der ausführlichen Nachrichten von der Königlich-Groß-Britannischen Colonie Salzburgischer Emigranten in America Erster Theil (Halle: in Verlegung des Wäysenhauses, 1741). Special Collections, A.R. Wentz Library, United Lutheran Seminary-Gettysburg. Photographed by author.

Together, the engravings of Tomochichi and his nephew and of Savannah County tell an evocative story of mission, transformation, and civilization that appealed to an audience eager for a story of not only the Salzburger Protestants' perseverance in the face of persecution and exile, but also of Protestant triumph over an unchurched and untamed wilderness. Tomochichi was a leader of the recently-formed Yamacraw community on the bluffs of the Savannah River. The Yamacraws were made up of former 
Lower Creeks and Yamasees that sought peaceful and advantageous trading relationships with the Europeans. Tomochichi developed a good relationship with James Oglethorpe and other early arrivals in Savannah and served as an important ally and mediator in negotiations between the English and the Lower Creeks in particular. He travelled to England with a delegation of Creeks, where he met the Georgia Trustees, King George II, Queen Caroline, William Wake, archbishop of Canterbury, and the artist William Verelst, who painted the portrait upon which the engraving is based. On his return trip to Georgia, Tomochichi journeyed with the first transport of Salzburger refugees and their Halle pastors (Sweet 2008; Weaver 2011, pp. 422-23; Urlsperger 1741, pp. 32-38).

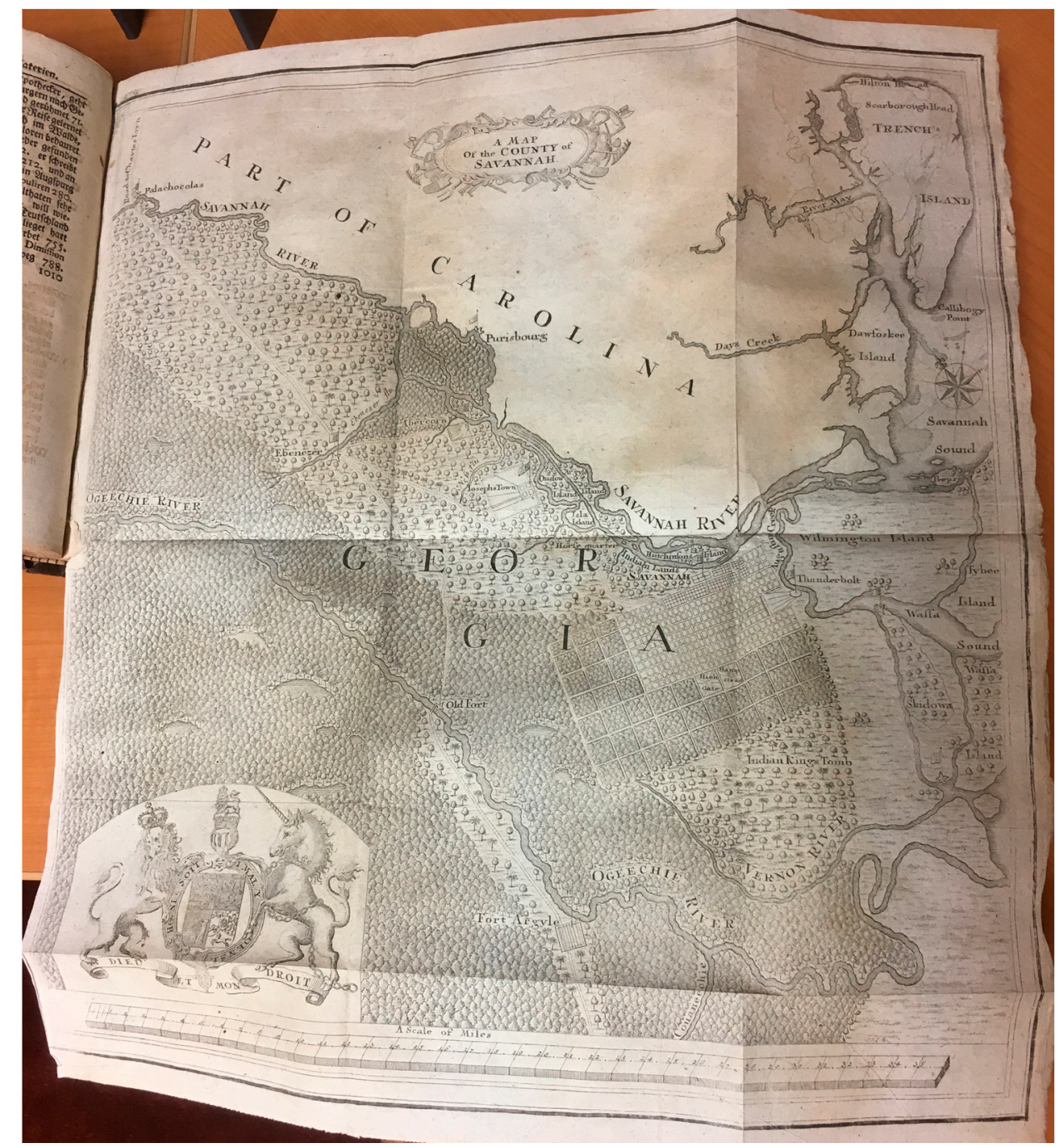

Figure 7. Engraving of Tomochichi and Toonahowi as it appears in the Detailed Reports (Urlsperger 1741). Samuel Urlsperger, ed. Der ausführlichen Nachrichten von der Königlich-Groß-Britannischen Colonie Salzburgischer Emigranten in America Erster Theil (Halle: in Verlegung des Wäysenhauses, 1741). Special Collections, A.R. Wentz Library, United Lutheran Seminary-Gettysburg. Photographed by author.

The portrait of Tomochichi and Toonahowi was carefully curated; to European audiences, they would have looked like Indians in a wilderness, who were, nonetheless, not particularly threatening. Tomochichi appeared noble in his bearing-according to Margaret Pritchard, Verelst depicted his deer skin draped over his shoulder in a manner similar to the way Verelst painted Oglethorpe's ermine cape in a contemporaneous portrait (n.d.). Tomochichi's deerskins were a symbol of his prestige; they 
were a valuable trading commodity of the Creek. He is portrayed with some wrinkles and yet does not appear as elderly as his supposed age (he was estimated at the time to be in his 80 s or 90 s). His hair is cropped with a central, long lock in the middle, which, together with his pierced ears and tattoos, identify him as a Creek warrior. The jungle-like wilderness behind him is, quite obviously, imagined by the London portraitist, although it might have seemed realistic enough to European audiences with little knowledge of the new Georgia colony. Tomochichi's nephew, Toonahowi, stands to his left holding an eagle. Toonahowi would be Tomochichi's successor within the matrilineal society of the Lower Creeks, and his significance is marked by the placement in his arms of the eagle - an important sign of peace among the Lower Creek and a diplomatic reminder of the eagle feathers the delegation had presented to the British king during their visit (Urlsperger 1741, p. 34; Sweet 2008, p. 152; Weaver 2011, p. 422).

Why did Urlsperger choose to include this engraving of Tomochichi in the published reports from Georgia? In addition to his portrait of Tomochichi and Toonahowi, Verelst had also completed a painting of the meeting of the Georgia Trustees with the entire delegation of Creeks, many of whom wore European-style clothing during their travels in England. Both paintings appear to have been completed without proper sittings and likely reflect Verelst's recollection and invention more than reality, but the portrait of Tomochichi and Toonahowi in their supposed native setting and garb spoke more to Urlsperger's purposes as outlined within the volume's foreword. There he presents Tomochichi as an earnest Indian, eager to engage European culture, and anxious-above all-to learn about Christianity. While Tomochichi's actual interest in Christianity is rather unclear and seems to have been, in part, imagined based on the conflation of his words with those of other Creeks and Cherokees in colonial Georgia, Urlsperger's description of Tomochichi repeatedly suggests a man seeking Christianity for both himself and his people (Sweet 2008, pp. 141-43; Urlsperger 1741, pp. 32-38). With this in mind, Urlsperger's choice of a depiction of Tomochichi within an invented Indian context—and yet with a welcoming and warm visage-makes a great deal of sense. The potential benefactors who opened and read this volume on the Foundations' first missionary effort to North America would find in the image an appealing and comprehensible call for support. Of course, the Halle ministers never found the time or purpose to pursue missions among the Creeks or Cherokees, but that vision did form part of the initial enterprise. In any case, Urlsperger likely realized the marketing value of the faces of unconverted Indians introducing the already dramatic story of the Salzburger refugees' settlement in colonial Georgia.

The first Salzburger report ends, then, with the engraving of the county of Savannah, which was based on a map attributed to Oglethorpe. The landscape Oglethorpe depicts is tidy and organized; the areas around Savannah have perfectly arranged and uniform trees, flags designate forts, and the city of Savannah is shown with its grid pattern, the lots growing larger in the squares more distant from the city center (each free settler received a city lot, a garden lot, and, furthest from the city, a farm). The grid design reflected, above all, the Trustees' interest in defense, but it also reflected a larger, Enlightenment-era interest in planning new cities, such as New Orleans, with attention to order and modern principles of rationality and transparency in design (Oglethorpe 1735; 2008; Dawdy 2008, pp. 27-32, 228).

Above all, the engravings of the map and of Tomochichi tell a story that frames the mission account within. It is an imperial story, on the one hand, sealed with the Royal Arms of Great Britain in the bottom left corner of the map. This story tells of a landscape transformed and civilized through the Georgia Trustees as approved representatives of the British crown. Through maps and images, in addition to settlements, laws, and wars, the Georgia Trustees claimed a new story about the Georgia landscape, one that they, the British empire, and partners like the Francke Foundations-but not the native peoples-could fulfill and tell. Missions were an inextricable part of this imperial story and success (Klassen 2018, pp. 7-9; Moniz 2016, pp. 14-16).

Alongside this imperial story-or, rather, integral to this imperial story-the use of these engravings in the Foundations' mission report also tells a story of Christian purpose, benevolence, and 
identity within the Georgia landscape. The engraving of Tomochichi and Toonahowi was placed to face the book's title page and the seal of the Foundations. In Toonahowi's arms, the Lower Creeks' eagle of peace and diplomacy sat opposite the soaring eagles of the Foundations' orphan house tympanum. The seal's farmer, sowing seeds in a well-plowed field, meanwhile, presaged the cultivated landscape of Savannah and its surroundings, as evidenced in the engraving of the map on the report's final page. Both engravings conveyed in large and vivid scale the same message as the Foundations' seal on the title page. The different (but recognizable) "noble Indian" and distant yet organized landscape reminded readers of the expanding, global stakes of Christian benevolence in an age of imperial expansion. While not reflective of the on-the-ground mission labors of Pietist ministers in Georgia, the Foundations' first report from North America nonetheless invited readers and potential benefactors to participate in the Christian work of the cultivation of new believers, new lands, and new political communities.

\section{Conclusions}

The Francke Foundations pursued their missionary and charitable goals with marketing savvy. They recognized the value of both their brand and their message. They sold products and raised needed funds while, at the same time, bringing together a dispersed community, including interested readers and benefactors, missionized Indians and Protestant refugees, disorganized Lutherans, the suffering and sick, ministers, and a variety of governing and colonial authorities. At once earthly "brand", theological message, and colonial claim, the Foundations' seal brought in money and sought to uplift those worn down by temporal anxieties and to turn their minds-like Muhlenberg's- to the "living picture ... of the matter there portrayed". No matter the obstacle, God's word should be extended to all, for who knew when and where the seeds of the gospel might "bring forth fruit"? The soaring eagles were to remind Christians of God's power to uplift the human soul in the tasks of mission and benevolence.

Through books, medicines, ministers, and money, the Foundations promoted their charitable labors as the fruition of Protestant belief and identity. This required an acute awareness of the Foundations' community and the audience of its materials-it was not only a matter of appealing to Pietist theological convictions surrounding missions, benevolence, and grace, but also of recognizing how Pietist communities were shaped by the imperial contexts in which they lived. The Foundations' missionary impulse mapped onto the colonial goals of the governments with which they worked, and this they demonstrated to participants, benefactors, and authorities through careful attention to marketing, message, and visual culture as well as through the dedicated communities they motivated and reached.

Funding: This article includes research completed with support from the Liselotte Kirchner Postdoctoral Fellowship at the Archive of the Francke Foundations and from a Faculty International Travel Award from the Graduate College of Missouri State University.

Acknowledgments: The author would like to thank the anonymous reviewers and the editors of this issue for their helpful comments and suggestions on previous drafts of the article. A very early version of this research was presented on a panel organized by Amanda Moniz at the 2016 Annual Conference of the Omohundro Institute of Early American History and Culture, which also provided valuable feedback.

Conflicts of Interest: The author declares no conflict of interest.

\section{References}

Anonymous. 1790. Die Gesellschaft zur Unterstützung der redlichen Hülfsbedürftigen Haus=Armen, in der Deutsch=Evangelisch= Lutherischen Gemeinde in Philadelphia, in dem Staat Pennsylvanien, in Nord=America. LAC H10 P5G3. Philadelphia: Lutheran Archives Center.

Anonymous. 2008. Oglethorpe and Savannah's City Plan. Savannah: Georgia Historical Society. Available online: http: / / georgiahistory.com/education-outreach/online-exhibits/featured-historical-figures/jamesedward-oglethorpe/savannahs-city-plan/ (accessed on 31 May 2018). 
Anonymous. n.d. Essentia Dulcis: Adventskalender, 15. Türchen. Franckesche Stiftungen. Available online: https:/ / www.francke-halle.de/einrichtungen-a-10012.html (accessed on 31 May 2018).

Anonymous. n.d. Tomochachi Mico (c. 1644-1739) and his Nephew Tooanahowi (c. 1719-1743). Winston-Salem: Museum of Early Southern Decorative Arts. Available online: http://mesda.org/item/collections / tomochachi-mico-c-1644-1739-and-his-nephew-tooanahowi-c-1719-1743/588/ (accessed on 31 May 2018).

Banner, Lois W. 1973. Religious Benevolence as Social Control: A Critique of an Interpretation. The Journal of American History 60: 23-41. [CrossRef]

Boltzius, Johann Martin. 1749. July 22 Letter to Henriette Rosine Goetze. Missionsarchiv der Franckeschen Stiftungen 5 B 1: 18.

Boltzius, Johann Martin. 2009. The Letters of Johann Martin Boltzius: Lutheran Pastor in Ebenezer, Georgia. Edited and translated by Russell Kleckley in collaboration with Jürgen Gröschl. Lewiston: Edwin Mellen Press.

Boltzius, Johann Martin, and Israel Christian Gronau. 1743. June 14 Letter to Johann August Majer. Missionsarchiv der Franckeschen Stiftungen 5 A 10:51.

Bowler, Kate, and Wen Reagan. 2014. Bigger, Better, Louder: The Prosperity Gospel's Impact on Contemporary Christian Worship. Religion and American Culture 24: 186-230. [CrossRef]

Bruun, Mette Birkedal, Sven Rune Havsteen, Kristian Mejrup, Eelco Nagelsmit, and Lars Nørgaard. 2015. Withdrawal and Engagement in the Long Seventeenth Century: Four Case Studies. Journal of Early Modern Christianity 1: 249-343. [CrossRef]

Conroy-Krutz, Emily. 2015. Christian Imperialism: Converting the World in the Early American Republic. Ithaca: Cornell University Press, ISBN 0801453534.

Curtis, Heather D. 2018. Holy Humanitarians: American Evangelicals and Global Aid. Cambridge: Harvard University Press, ISBN 0674737369.

Davis, Natalie Zemon. 1975. Poor Relief, Humanism, and Heresy. In Society and Culture in Early Modern France. Edited by Natalie Zemon Davis. Palo Alto: Stanford University Press, ISBN 0804709726.

Dawdy, Shannon Lee. 2008. Building the Devil's Empire: French Colonial New Orleans. Chicago: University of Chicago Press, ISBN 0226138437.

Dayton, Cornelia H., and Sharon V. Salinger. 2014. Robert Love's Warnings: Searching for Strangers in Colonial Boston. Philadelphia: University of Pennsylvania Press, ISBN 0812224043.

Finch, Martha. 2009. Dissenting Bodies: Corporealities in Early New England. New York: Columbia University Press, ISBN 0231139462.

Francke, August Hermann. 1704. Sonn-Fest-und Apostel-Tags-Predigten. Halle: Wäysenhause.

Francke, August Hermann. 1709. Segensvolle Fußstapfen des noch lebenden und waltenden liebreichen und getreuen Gottes. Halle: Wäysen-Hauses.

Francke, August Hermann. 1731. Erklaerung der Psalmen Davids. Halle: Verlegung des Wäysen-Hauses.

Frohman, Larry. 2008. Poor Relief in Germany from the Reformation to World War I. New York: Cambridge University Press, ISBN 0801453534.

Grundler, Gottfried August. 1749. The Francke Foundations in Halle.

Hall, David D. 1989. Worlds of Wonder, Days of Judgment: Popular Religious Belief in Early New England. Cambridge: Harvard University Press, ISBN 0674962168.

Haskell, Thomas L. 1985. Capitalism and the Origins of the Humanitarian Sensibility, Part 1. The American Historical Review 90: 339-61. [CrossRef]

Henckel von Donnersmark, Erdmann Heinrich. 1722. Die letzten stunden. Halle: Wäysenhaus.

Hindmarsh, D. Bruce. 2018. The Spirit of Evangelicalism: True Religion in a Modern World. Oxford: Oxford University Press, ISBN 0190616695.

Klassen, Pamela. 2018. The Story of Radio Mind: A Missionary's Journey on Indigenous Land. Chicago: University of Chicago Press, ISBN 022655273X.

Koch, Philippa. 2016. Experience and the Soul in 18th-Century Medicine. Church History 85: 552-86. [CrossRef]

Leaman, Hans. 2014. Johann Christoph Sauer (1695-1758). Immigrant Entrepreneurship: German-American Business Biographies, 1720 to the Present. February 28. Available online: http://www. immigrantentrepreneurship.org/entry.php?rec=195 (accessed on 31 May 2018).

Leith, John H., ed. 1963. Creeds of the Church: A Reader in Christian Doctrine from the Bible to the Present, 3rd ed. Louisville: Westminster John Knox Press, ISBN 0804205264. 
Marschke, Benjamin. 2014. Pietism and Politics in Prussia and Beyond. In A Companion to German Pietism, 1660-1800. Edited by Douglas Schantz. Leiden: Brill, ISBN 9004226095.

McCarthy, Kathleen D. 2003. American Creed: Philanthropy and the Rise of Civil Society, 1700-1865. Chicago: University of Chicago Press, ISBN 0226561984.

McDannell, Colleen. 1995. Material Christianity: Religion and Popular Culture in America. New Haven: Yale University, ISBN 0300074999.

Mejrup, Kristian. 2015. Halle Pietism: Acrobats Buying Time. In Antropological Reformations: Anthropology in the Era of Reformation. Edited by Anne Eusterschulte and Hannah Wälzholz. Göttingen: Vandenhoeck \& Ruprecht, ISBN 3647550582.

Melton, James Van Horn. 2008. From Alpine Miner to Low-Country Yeoman: The Transatlantic Worlds of a Georgia Salzburger 1693-1761. Past E Present 201: 97-140. [CrossRef]

Minardi, Lisa. 2013. Philadelphia, Furniture, and the Pennsylvania Germans: A Reevaluation. In American Furniture. Edited by Luke Beckerdite. Milwaukee: Chipstone, ISBN 0982772238.

Moniz, Amanda. 2016. From Empire to Humanity: The American Revolution and the Origins of Humanitarianism. Oxford: Oxford University Press, ISBN 0190240350.

Morgan, David. 1998. Visual Piety: A History and Theory of Popular Religious Images. Berkeley: University of California, ISBN 0520219325.

Muhlenberg, Henry Melchior. 1942. The Journals of Henry Melchior Muhlenberg. Translated by Theodore G. Tappert, and John W. Doberstein. Philadelphia: Evangelical Lutheran Ministerium of Pennsylvania and Adjacent States, vol. 1.

Müller-Bahlke, Thomas. 2000. Communication at Risk: The Beginnings of the Halle Correspondence with the Pennsylvania Lutheran. In In Search of Peace and Prosperity: New German Settlements in 18th-Century Europe and America. Edited by Hartmut Lehmann, Hermann Wellenreuther and Renate Wilson. University Park: Pennsylvania State University, ISBN 0271019298.

Niekamp, Johann Lucas, ed. 1740. Kurtsgefastzte Missions-Geschichte oder Historischer Auszug der evangelischen Missions-Berichte aus Ost-Indien von dem Jahr 1705 bis zu Ende des Jahres 1736. Halle: Verlegung des Wäysen-Hauses.

O'Hanlon, Michael E., and Anne Turner. 2017. The Prosperity Gospel's Shallow Preaching. Washington: Brookings, February 5. Available online: https://www.brookings.edu/opinions/the-prosperity-gospels-shallowpreaching/ (accessed on 31 May 2018).

Oglethorpe, James Edward. 1735. A Map of the County of Savannah. In Der Ausführlicche Nachrichten. Edited by Samuel Urlsperger. Columbus: Columbus State University Archives. Available online: http:/ / digitalarchives.columbusstate.edu/items/show / 19 (accessed on 30 May 2018).

Oliver, John. 2015. Televangelists. Last Week Tonight with John Oliver. August 16. Available online: https: / / www.youtube.com/watch?v=7y1xJAVZxXg (accessed on 31 May 2018).

Osborn, Sarah. 1758. Diary entry for February 21. Sarah Osborn, Diary (February 19-April 2 1758), Newport Historical Society, Newport RI.

Pendergrass, Drew. 2017. The Televangelist-in-Chief: Trump and the Prosperity Gospel. Harvard Political Review, November 12. Available online: http:/ / harvardpolitics.com/culture/tevangelistinchief/ (accessed on 31 May 2018).

Pettegree, Andrew. 2015. Brand Luther: How an Unheralded Monk Turned his Small Town into a Center of Publishing, Made Himself the Most Famous Man in Europe-and Started the Protestant Reformation. New York: Penguin, ISBN 0399563237.

Powers, Nicholas. 2018. We Need the Revolutionary Black God that James Cone Saw. Huffpost, May 18. Available online: https:/ / www.huffingtonpost.com/entry / powers-opinion-james-cone-black-liberation-theology_ us_5afc3a5ae4b0a59b4dff7639 (accessed on 31 May 2018).

Promey, Sally M. 2011. Hearts and Stones: Material Transformations and the Stuff of Christian Practice in the United States. In American Christianities: A History of Dominance \& Diversity. Edited by Catherine A. Brekus and W. Clark Gilpin. Chapel Hill: University of North Carolina Press, ISBN 080787213X.

Roberts, William. 1893. Printers' Marks: A Chapter in the History of Typography. London: George Bell \& Sons.

Roeber, Anthony G. 1997. J. H. C. Helmuth, Evangelical Charity, and the Public Sphere in Pennsylvania, 1793-1800. The Pennsylvania Magazine of History and Biography 121: 77-100. 
Ryan, Susan M. 2004. The Grammar of Good Intentions: Race and the Antebellum Culture of Benevolence. Ithaca: Cornell University, ISBN 0801489857.

Sweet, Julie Anne. 2008. Will the Real Tomochichi Please Come Forward? American Indian Quarterly 32: 141-77. [CrossRef]

Urlsperger, Samuel. 1735. March 17 Letter to Gotthilf August Francke. Francke-Nachlaß der Staatsbibliothek zu Berlin 21,2,2/8: 199.

Urlsperger, Samuel, ed. 1741. Der ausführlichen Nachrichten von der Königlich-Groß-Britannischen Colonie Salzburgischer Emigranten in America Erster Theil. Halle: in Verlegung des Wäysenhauses.

Veltmann, Claus. 2013. August Hermann Francke und die “Marke” Waisenhaus. Kulturfalter, April. Available online: http:/ / www.kulturfalter.de/magazin/stadtgeschichte/april-2013-hallesches-waisenhaus-augustfrancke/ (accessed on 31 May 2018).

Walker, Mack. 1992. The Salzburg Transaction: Expulsion and Redemption in 18th-Century Germany. Ithaca: Cornell University Press, ISBN 0801427770.

Wallmann, Johannes. 2005. Der Pietismus. Göttingen: Vandenhoeck \& Ruprecht, ISBN 3825225984.

Wandel, Lee Palmer. 2003. Always among Us: Images of the Poor in Zwingli's Zurich. Cambridge: Cambridge University Press, ISBN 0521522544.

Ward, W. R. 1992. The Protestant Evangelical Awakening. Cambridge: Cambridge University Press, ISBN 0521414911.

Weaver, Jace. 2011. The Red Atlantic: Transoceanic Cultural Exchanges. American Indian Quarterly 3: 418-63. [CrossRef]

Whitefield, George. 1742. A Continuation of the Account of the Orphan-House in Georgia, from January 1740/1 to June 1742. Edinburgh: Lumisden and Robertson.

Wilson, Renate. 2000. Pious Traders in Medicine: A German Pharmaceutical Network in 18th-Century North America. University Park: Pennsylvania State University, ISBN 0271020520.

Wright, Conrad Edick. 1992. The Transformation of Charity in Postrevolutionary New England. Boston: Northeastern University Press, ISBN 1555531237.

(C) 2018 by the author. Licensee MDPI, Basel, Switzerland. This article is an open access article distributed under the terms and conditions of the Creative Commons Attribution (CC BY) license (http:/ / creativecommons.org/licenses/by/4.0/). 